\title{
Russia's new science survivors
}

\author{
The survival of a core of the Russian research enterprise seems more certain now than for several months. That \\ prospect is the achievement of the research minister for the past three years.
}

Moscow. Boris G. Saltykov, Russia's minister for research, was in a cheerful mood a week ago: he had been travelling about, talking to researchers and visiting some of the sites at which, even now, there are funds to support new developments. He was especially proud that the Russian particlephysics community (in partnership with Germany's DESY laboratory at Hamburg) has thought of using the great depth of Lake Baikal to bury a neutrino-detector beneath 1,000 metres of the world's most pristine water (now being shipped onto the international table-water market in plastic bottles). Construction is well under way. The implication is that Russian science will survive.

If true, that will owe as much to Saltykov and to his survival so far as to any other circumstance. Indeed, last week he wryly pointed out that, in a news report of the "special" (and really quite extraordinary) meeting of the old Soviet Academy of Sciences at which it was decided that the academy would become the Russian Academy of Sciences and at which Saltykov made his first public appearance as Minister for Higher Education and Research, this journal reported the views of some who held that he was "too intelligent to survive". "But look," he said last week, "I'm still here."

It has not always been like this. On a visit to London at the end of 1992, and with the trouble between President Boris Yeltsin and the parliament (Duma) reaching one of several climaxes, Saltykov confessed one evening that he did not know what job, if any, he would return to on the following day's aircraft. What happened was simply that responsibility for higher education was reassigned to another minister.

So Saltykov has good reason to feel secure. His intelligence has proved an asset, not a handicap. His well-mannered modesty works in the same direction. And whoever, in previous regimes, heard of a minister who visited dependent researchers in their own laboratories or in the field, when they could more conveniently be summoned to Moscow to make a presentation of their work?

Not that life is trouble-free. There is, for example, the endless problem of money. Half-way through the financial year, it is still not clear how much money will materialize for the second half. The only certainty is that it will be insufficient. Saltykov is not surprised that a number of research institutes have been compelled to give their staffs unpaid leave during the long (but unusually cool) summer.

Indeed, the ministry seems to willing to superintend a system of survival by natural selection. The institutes complaining that they cannot recruit graduate students, and which therefore worry about their future, are simply not paying them well enough. The institutes have to increase their income somehow. Successful institutes manage well

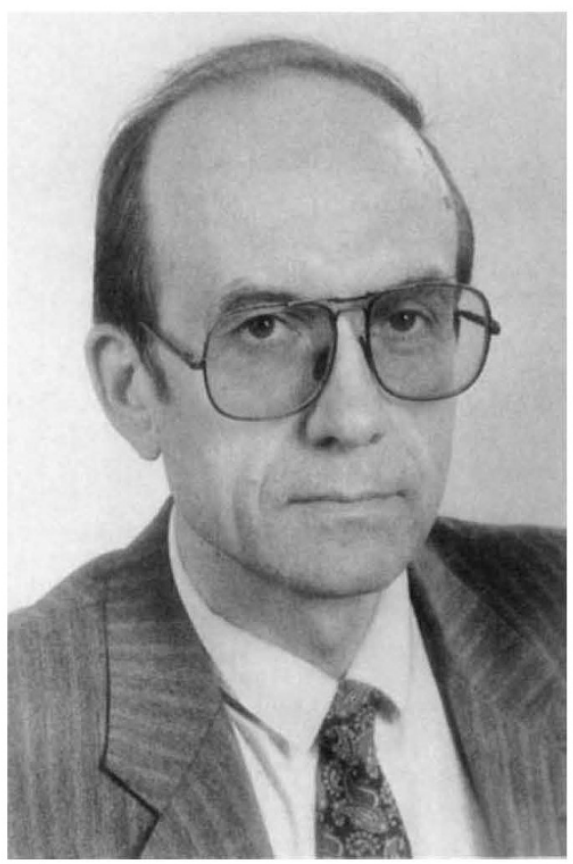

Saltykov is still there ....

enough, and their senior people are in good shape, earning between 200,000 and 500,000 rubles (the equivalent of $\$ 100$ to $\$ 250$ ) a month, perhaps with a spell of three to four months overseas each year.

Saltykov last week cited what seems to him a case of successful research entrepreneurship. A group of laser physicists at St Petersburg, having failed to win extra resources from the Physical Technical Institute, moved out to found their own laboratory and are now doing well, partly with the help of research contracts from abroad. If to survive is to live well, wit is a precondition.

Whether high-energy physics will manage to survive in Russia is another question. Saltykov says "I'm glad it's not my problem", but the accelerator laboratory at Serpukhov is now jointly financed by the ministries for atomic energy and for research. Construction of a $400 \mathrm{GeV}$ proton accelerator was well under way eight years ago (see Nature 329, 789; 1987), but even the 'warm magnet' accelerator, intended to produce protons at $400 \mathrm{GeV}$, is still two or three years from completion. Ambitions to install superconducting magnets in the same $27-\mathrm{km}$ tunnel to produce protons at $3 \mathrm{TeV}$ are in abeyance. Inevitably, it has become a live issue to decide whether the installation should be finished. Saltykov says he does not know how the question will be decided, but notes that Russian scientists have access to CERN at Geneva and DESY as well as to Russian machines at St Petersburg and Novosibirsk. Saltykov is much more secure than Serpukhov.

On relations with the Russian academy, Saltykov said last week that "we're now in a calm period", meaning that the academy, while still asserting its right of access to the prime minister directly, is willing to talk to his own ministry as well. He hopes to build on that by inviting the academy's advice on science policy issues. As the academy's direct influence on research declines with its declining share of most institutes' budgets, that could be a constructive development.

Otherwise, Saltykov's chief concern is with the need to break new ground in the development of previously neglected institutions. Industrial research is still mostly concentrated in ministry (and academy) institutes; there is no immediate prospect that even newly privatized industries will set up their own research facilities. But that, Saltykov says, is a measure of the degree to which direct foreign investment in Russia has fallen behind the promises of the past few years. With the exception of George Soros's "excellent example of direct investment in Russian science", he said last week, "I'm still waiting to see it".

On the future of Russian universities, Saltykov is also sanguine. In language that might be heard from almost any education minister in the West, he notes that there are perhaps a dozen universities of the first rank among Russia's eighty, but again it is plain that their future as centres of research will hang on their people's flair for raising funds, perhaps from the Soros funds or perhaps from the government's own research foundation. In such hard times, there is no choice.

In all the circumstances, Saltykov is entirely right to be pleased with himself, and with his own survival in his post. He took office when rubles were worth 2,000 times what they are at present. The government has been through a succession of crises, including one in which it called out the tanks to shell the Duma. But now, despite the persisting problems, he seems to have assured the future of at least a core of Russian science. Perhaps the intelligence was a help, after all.

John Maddox 